\title{
As análises da memória militar sobre a ditadura: balanço e possibilidades
}

Studies of military memory of Brazilian
dictatorship: balance and possibilities

Cláudio Beserra de Vasconcelos

O pesquisador que opta por trabalhar sobre a ditadura instaurada no Brasil em 1964 enfrenta o obstáculo do acesso à documentação produzida pelo regime. Esse problema vem sendo paulatinamente resolvido com a abertura dos arquivos da época. Todavia, hoje, esse processo ainda é parcial e, ao que parece, continuará lento e gradual.

Visando a suprir essa lacuna, o uso da fonte oral tem oferecido bons resultados e apresenta iguais perspectivas. Entre esse tipo de fonte, tem recebido especial atenção dos analistas a memória dos militares partícipes do golpe e do regime implantado em 1964. Tais análises apresentam dados significativos que

Cláudio Beserra de Vasconcelos é doutorando do Programa de Pós-Graduação em História Social da UFRJ e membro do Laboratório de Estudos sobre os Militares na Política (LEMP/UFRJ) (cb.vasconcelos @yahoo.com.br).

Artigo recebido em 15 de dezembro de 2008 e aprovado para publicação em 19 de fevereiro de 2009.

Estudos Históricos, Rio de Janeiro, vol. 22, nº 43, janeiro-junho de 2009, p. 65-84. 
ajudam a compreender esse período de nossa história e questões específicas da construção da memória. Mas, a meu ver, elas apresentam limites: nem todas atentam para os aspectos constitutivos da memória; em geral, tomam os relatos apenas como uma réplica às análises acadêmicas e às memórias da esquerda; não têm dedicado atenção semelhante à perspectiva de outro grupo de personagens igualmente importante para a compreensão do período: os militares cassados após o golpe.

Não tenho o intuito de oferecer conclusões aprofundadas sobre tais pontos. O objetivo é bem mais modesto. Interessa-me destacar algumas questões a serem observadas em estudos sobre a memória e, a partir delas, em discussão com os trabalhos que julgo mais significativos sobre a memória militar, ${ }^{1}$ levantar os limites destes e apontar perspectivas que, creio, se bem observadas, podem enriquecer as análises sobre a ditadura que tomam as fontes orais como objeto.

\section{As análises das vozes dos vitoriosos em 1964}

Há três aspectos constitutivos da memória que não podem ser ignorados. ${ }^{2} \mathrm{O}$ primeiro refere-se à seleção do que deve ser lembrado. $\mathrm{O}$ testemunho nunca é um relato exato do que aconteceu. Na verdade, ao expor seu passado, o depoente está sempre procedendo a uma reelaboração através da qual memórias tidas como negativas podem, consciente ou inconscientemente, ser esquecidas. Em certos momentos, para que determinado projeto político seja vitorioso, ou simplesmente para seguir em frente, é preciso esquecer.

Outro aspecto reside no fato de que essa reelaboração do passado não se baseia em uma memória individual impermeável às influências externas. Como define Maurice Halbwachs (1990: 26), construímos nossas lembranças na interação com a sociedade, seus grupos e instituições. Portanto, a memória individual existe sempre a partir de uma memória coletiva, que também é seletiva. Todas as lembranças são constituídas no interior de um grupo, e em contato com as lembranças dos outros. Logo, a memória é sempre fruto de uma interação entre diferentes agentes, internos e externos.

$\mathrm{O}$ terceiro aspecto refere-se ao fato de as pessoas construírem suas memórias na interrelação entre passado e presente. Como a memória atua no presente para representar o passado, e como as situações do presente variam, essa interpretação do passado pode sofrer modificações em função do momento em que é articulada.

Gláucio Ary Dillon Soares (1994) parece desconsiderar esses aspectos quando analisa a memória dos militares que participaram da tomada do poder em 1964 e do regime então implantado. Trabalhando com depoimentos colhidos em projeto desenvolvido junto ao CPDOC/FGV, e também com obras elabora- 
das com base em entrevistas de militares, tenta comparar as explicações privilegiadas pela literatura acadêmica com aquelas apresentadas pelos militares que participaram do golpe e do regime. ${ }^{3}$ Como resultado, observa que, na literatura acadêmica sobre os golpes militares ocorridos nos países latino-americanos a partir da década de 1960, as explicações fixam-se em fatores de ordem econômica, como a redução da taxa de crescimento, o fim da etapa "fácil" de substituição das importações ou a exaustão do modelo de industrialização substitutiva das importações. No caso brasileiro, acrescentam-se referências à inabilidade de um governo de tipo populista para sobreviver em um período de estagflação, à frágil base de apoio político de Jango e à paralisia decisória, decorrente da alta rotatividade de ministros e diretores de empresas públicas (Soares, 1994: 13-22).

Já nos relatos dos militares, o autor identifica como principais explicações para o golpe, em ordem de relevância, o caos, a desordem, a anarquia e a instabilidade política; o perigo comunista, sindicalista esquerdista; e questões militares como a crise hierárquica militar e a interferência do governo em assuntos internos da corporação. Nos depoimentos desses atores o golpe é visto como uma conspiração militar que teve o apoio de grupos econômicos nacionais (Soares, 1994: 35-37). Os fatores privilegiados pelos acadêmicos, como as questões de ordem econômica ou a participação dos Estados Unidos, são pouco ou nada mencionados, apresentando, portanto, de acordo com Soares (1994: 44-45), uma importância apenas marginal. Para o autor, a ausência de explicações que façam referência a fatores econômicos se justifica pela falta de familiaridade dos militares com eles e indica que o golpe foi essencialmente político. Já quanto à participação dos Estados Unidos, uma negação vigorosa poderia indicar um embaraço, mas o consenso na ausência de referências indica que foi irrelevante.

É inegável que há divergências entre as análises acadêmicas e os relatos dos militares. Para Soares, isso ocorre devido à falha da literatura acadêmica em relacionar o macro com o micro. Para solucionar esse problema, Soares sustenta que não basta ater-se a fatores explicativos gerais, que, segundo ele, não provam, não demonstram. É preciso analisar as razões explicativas dos militares e realizar um exercício empírico (Soares, 1994: 46). A seu ver, o estudo do comportamento militar sem um contato direto, sem entrevistas, sem acesso a fontes documentais e testemunhais, não possibilita a correção do dado. Tratado com base em elementos de outra natureza, como por exemplo estatísticas econômicas, o comportamento militar aparece como mera extensão destes (Soares, 1994: 27).

Gláucio Soares parte da concepção de que os militares são uma categoria com um alto grau de especificidade e de isolamento social. Nesse sentido, propõe pesquisá-los diretamente, e não aconselha a análise de seu comportamento a partir de teorias baseadas em outras instituições, grupos ou classes. Tampouco seria adequado observar os eventos dos quais eles participaram decisivamente com base em teorias e dados sobre a sociedade (Soares, 1994: 46). Parece-me, porém, 
que Soares incide em erro semelhante ao que critica (a fixação dos cientistas sociais no macro, ignorando o micro), embora em sentido contrário: opta pelo micro, ou melhor, por uma parte dele - o relato dos militares que participaram do regime -, sem relacioná-lo com o macro, com a conjuntura em que ocorreu o golpe e se desenvolveu o regime. A defesa da tese do isolamento da corporação militar faz com que Soares se fixe nos testemunhos dos militares e deixe de atentar para os aspectos fundamentais da constituição da memória mencionados anteriormente.

Não se pode negar a especificidade dos militares. Também é correto afirmar que questões relativas à ordem e à hierarquia são constitutivas e fundamentais do comportamento militar. Mas isso não os torna impermeáveis às influências de grupos civis. Além disso, não é porque não aparecem - ou aparecem pouco explicações referentes às questões de ordem econômica, político-ideológica e de política internacional, que esses fatores são menos importantes. De modo diverso, não creio que exista um suposto alto grau de autonomia dos militares em relação à sociedade civil. Suas tomadas de posição são decididas com base em prismas institucionais, mas levando em consideração as influências do meio social. Com a memória ocorre o mesmo. Ela é construída com base na interação permanente entre os próprios militares pró-regime, e destes com a instituição militar e seus aliados civis, mas também com seus opositores (civis e militares). Na análise de Soares, a opção pela tese do isolamento militar leva-o a não observar esse caráter coletivo da construção da memória. Também não parece que ele tenha dado a devida atenção ao momento em que essas memórias foram produzidas.

O material com que o autor trabalha foi quase que totalmente elaborado a partir da segunda metade dos anos 1970, ou seja, no momento em que os militares já se preparavam para se retirar do poder e/ou após esse fato. Portanto, representa um balanço do regime feito em um momento de crise, quando os militares eram muito criticados. Qualquer avaliação desse período, por esses atores, leva esses fatos em consideração. Logo, qualquer interpretação sobre memórias militares produzida naqueles dias não poderia ignorá-los. Não creio, porém, que Soares tenha concedido a essa questão a importância devida. Em complemento, não observou que em função dessa interação entre presente e passado ocorre o silenciamento de partes deste, tidas como inadequadas à reelaboração da memória que estava em processo.

Na segunda metade dos anos 1970, o milagre econômico tornava-se um sonho distante. Em meio a esse quadro, se os militares justificassem o golpe com base na crise econômica do início dos anos 1960, apenas reforçariam o argumento daqueles que queriam a separação entre poder político e poder militar. Afinal, se eles chegaram ao poder com a missão, entre outras, de corrigir os erros da economia e não conseguiram, por que mantê-los lá? Além disso, as denúncias sobre 
a repressão se avolumavam, as críticas ao regime se intensificavam. Por esses motivos, relembrar sua missão salvadora de livrar o Brasil do comunismo era tanto uma tentativa de justificar a repressão quanto uma forma de reconstruir sua imagem, tão abalada pelos anos de regime arbitrário.

Elaborando um estudo mais atento aos aspectos constitutivos da memória do que o feito por Gláucio Soares, Aline Prado Atassio (2007) também analisa a memória de oficiais partidários do golpe e do regime instalado em 1964. Seu objetivo, porém, é buscar a existência de uma história oficial do Exército sobre o tema, transmitida a seus membros pela instituição e sedimentada no imaginário desses homens. Com essa meta, trabalhando com outro corpo de depoimentos a coleção publicada pela Biblioteca do Exército Editora (Bibliex) - ${ }^{4}$ a autora detecta a interrelação entre passado e presente existente na constituição dos relatos. Observa que os depoimentos foram elaborados como uma resposta às análises acadêmicas e relatos civis, ou seja, à memória dominante - considerada revanchista pelos militares - construída em torno do regime (Atassio, 2007: 11-12,14), e conclui que é notável nos relatos um esforço de reconstrução do passado a partir de uma questão que atingia os militares no momento da elaboração da coleção e da coleta dos depoimentos, conclusão ausente no estudo de Soares.

Da mesma forma, a autora destaca o caráter coletivo da memória, ao verificar que as reconstruções individuais apresentadas são sempre reproduções da memória do grupo social do depoente, no caso específico, o Exército (Atassio, 2007: 172). Esse aspecto fica nítido a partir da constatação de vícios metodológicos na realização das entrevistas. A autora adverte que os princípios de escolha dos entrevistados não foram muito claros, e tiveram como base parâmetros estabelecidos pela hierarquia militar (Atassio, 2007: 12-13). Como afirma, o objetivo da coleção

não era polemizar mais ainda sobre o tema e sim escrever discursos homogêneos capazes de adquirirem, pela repetição, coloração de verdade - o que pode ter sido alcançado através da escolha "a dedo" dos depoentes. Conhecendo a posição do entrevistado sobre o tema pode o entrevistador prever suas respostas. (Atassio, 2007: 20)

De modo semelhante, "a escolha das questões obedeceu a critérios que atendiam aos interesses das Forças Armadas em defender a instituição, justificar a intervenção e responder à oposição" (Atassio, 2007: 13). Como resultado, surgiram discursos "individuais" que refletiam um discurso institucional justificado como sendo de importância social, por mostrar o lado que na visão do grupo estava sendo ocultado pela memória dominante. 
Os avanços em relação à interpretação de Soares são nítidos, mas Atassio também não resiste à interpretação militar para as razões do golpe. A autora igualmente discorda das análises que determinam como razão explicativa para a ação o anticomunismo, as questões sociais, as disputas político-ideológicas ao longo dos anos anteriores e as divergências com relação à política implementada pelo governo de João Goulart, mas não apresenta a pluralidade de motivos presente no estudo de Gláucio Soares. Para Atassio (2007: 177), o ponto nodal foi unicamente a questão hierárquica, mais precisamente, a intensificação dos movimentos das praças militares a partir de 1963. Contudo, essa questão aparece apenas de modo secundário em seu trabalho, enquanto na análise de Soares é o objetivo central.

Questiono tais argumentos porque creio que um estudo que pretenda apresentar conclusões sobre as razões do golpe de 1964 a partir dos relatos dos envolvidos não pode desconsiderar os fatores conjunturais, os aspectos constitutivos da memória - como me parece ter feito Soares - e deve ser o mais abrangente possível no que se refere ao conjunto de depoimentos a ser estudado. Os analistas não observam as explicações de outros grupos de atores que também tiveram participação efetiva naquela conjuntura. Não creio que sejam contrários a essa possibilidade. Provavelmente o escopo dos trabalhos não abria espaço para tanto, mas um exame, por exemplo, das memórias de militares que se opuseram ao regime pode levar a conclusões diferentes.

Típico dessa divergência é o relato/análise de Nelson Werneck Sodré (s.d.: 26), militar, professor e intelectual nacionalista, sobre o golpe militar. As explicações de Sodré baseiam-se fundamentalmente em fatores que remetem à conjuntura política internacional de conflito político-ideológico entre nações e à intervenção do imperialismo norte-americano na política brasileira, de modo geral, e nas Forças Armadas, em particular. E mesmo para simpatizantes do golpe, como o coronel Cyro Etchgoyen, cujo depoimento foi analisado por Soares, as razões são mais complexas. Para o coronel, havia vários fatores que o levaram a concluir pela inevitabilidade do golpe, mas estes não tinham peso igual. Para ele, os de ordem político-econômica foram os mais importantes (Soares, 1994: 44). Mas essa foi uma razão fundamental no relato deste militar e não nos dos demais. Através da metodologia empregada por Soares, tornou-se um fator marginal.

\section{O esquecimento na memória pública e na fala dos militares}

Não há como lembrar tudo o que ocorreu em uma vida e, muito menos, contar. Por isso, toda construção na história deixa fora algumas coisas e conserva as consideradas mais relevantes para o episódio relatado. $\mathrm{O}$ que difere são as for- 
mas de esquecer alguns fatos e questões. Existe um primeiro esquecimento que é passivo, fruto da limitação humana de lembrar-se de tudo. Há, porém, outro, que é deliberado e pode decorrer da impossibilidade do indivíduo de lidar com determinado trauma ou ser resultado de um projeto político. Quanto a este último tipo, ele pode derivar da disputa pela constituição da memória pública. Nesse processo, a que se torna dominante impõe o "silêncio" a outras que poderiam ir de encontro às suas premissas. Mas as memórias relegadas aos subterrâneos pela dominante, na tentativa de romper a barreira que lhe é imposta e se fazer ouvir, também podem, conscientemente, silenciar sobre algumas lembranças tidas como negativas.

Essa questão fica bastante clara nos relatos dos militares que participaram do regime. Com base nas análises que Aline Prado Atassio (2007), Maria Celina D'Araujo (1994) $)^{5}$ e João Roberto Martins Filho (2002) ${ }^{6}$ fazem desses discursos, é possível destacar dois exemplos de como a memória sobre a ditadura brasileira é construída "esquecendo" determinada parte da história: o esquecimento da memória pública, que é questionado pelos militares que participaram do regime; e o esquecimento desses mesmos militares de determinadas questões que poderiam afetar tanto a eles próprios, particularmente, quanto à instituição, negativamente.

Com relação ao primeiro aspecto, um dos pontos centrais presente nas recordações desses homens é o sentimento de derrota em relação ao tipo de memória que a sociedade constituiu sobre eles (D’Araujo, 1994: 151). Os militares se apresentam como se tivessem sido julgados apenas por seus erros e fracassos e não por suas realizações. Ressentidos, consideram-se traídos pela sociedade e defendem a tese de que o golpe foi uma iniciativa não só deles, mas também dos civis, principalmente por terem sido estes a clamar pela intervenção e pela permanência dos militares no poder. Além disso, enfatizam que a oposição civil combatida por eles era o mesmo grupo que as elites civis que apoiaram o regime queriam eliminar. Para os militares, essa "parceria" civil-militar teria sido rapidamente esquecida após o fim do regime (D’Araujo, 1994: 155-158). Percebe-se, nesse caso, que a memória pública silencia em um aspecto que é questionado por esse grupo de militares. Contudo, eles agem de modo semelhante.

Buscando resgatar a honra e o prestígio perdidos, nos relatos dos militares os erros, fraquezas e vacilações são ignorados, enquanto os supostos acertos, as virtudes e a força - dos governos, da instituição e dos indivíduos - são valorizados (Atassio, 2007: 172). Com esse intuito, os excessos são justificados pela necessidade de preservação do governo e como resposta às ações dos opositores. Portanto, admitem que eles ocorreram, mas os apresentam como necessários à realização de sua missão salvadora de eliminação das ideologias extremistas. 
Além disso, esses excessos são postos como atos isolados de alguns e não da corporação (Atassio, 2007: 161 e 166, D’Araujo, 1994: 159-161 e 170; Martins Filho, 2002: 193). ${ }^{7}$

É ponto pacífico que os relatos dos militares foram construídos como réplicas. Atassio (2007: 11-12 e 14) e Martins Filho (2002: 182 e 189) mencionam que são respostas às análises acadêmicas e aos relatos civis de esquerda, ou seja, à memória dominante construída em torno do regime. Creio, porém, que a questão é um pouco mais complexa, envolvendo também os civis partícipes do regime. Embora os relatos civis que tiveram repercussão sejam de militantes de esquerda, não se pode ignorar o fato de que essa construção favoreceu muito um grupo de políticos que havia participado do regime. Livres do estigma de parceiros da ditadura, homens como José Sarney, Aureliano Chaves, Antônio Carlos Magalhães e Marco Maciel - para citar apenas os mais destacados - puderam continuar frequentando os círculos do poder no período posterior. Por essa razão, creio que a indignação e a réplica dos militares também se referem a esse silêncio.

Também não se contesta o fato de a memória pública silenciar sobre determinados aspectos da ditadura. Contudo, os militares constroem suas memórias do mesmo modo. É preciso reconhecer que muitos fazem uma autocrítica de seu período no governo. Lamentam não terem voltado para os quartéis em um momento econômico melhor para o país, e sim em uma crise; expressam que o exercício do poder não é um papel das Forças Armadas; reconhecem ter exagerado na confiança de que fariam sempre as melhores opções para o país, e também a prática de excessos na repressão, embora sempre frisem que estes eram obra de alguns. Todavia, essa autocrítica não esconde os silêncios nos relatos desses homens que, ao tentar combater a memória construída, que associa os excessos e os fracassos do regime apenas aos militares, se não omitem completamente os erros e abusos praticados, os interpretam de modo a resgatar o prestígio perdido. Nesse processo, é ignorado, ou ao menos amenizado, o caráter autoritário da tomada e do exercício do poder, assim como os conflitos político-ideológicos inerentes à questão.

Creio que, com base nos argumentos militares e nas considerações dos analistas, ocorreu no Brasil um processo semelhante ao que Andréas Huyssen (2004: 16) notou ter acontecido na Argentina dos anos 1980 e na Alemanha do pós-Segunda Guerra: o esquecimento público esteve a serviço de uma política da memória que, em última instância, forjou um consenso nacional em torno de determinada ideia. ${ }^{8}$ No que se refere especificamente ao caso brasileiro, em função dos relatos dos militantes da esquerda e das análises acadêmicas, e por interesses de grupos políticos civis, foi gerada uma memória que ligou estritamente a ditadura ao elemento militar, silenciando sobre a participação de grupos civis. Essa 
construção, no meu entender, se por um lado afetou os militares envolvidos diretamente no período ditatorial, por outro, beneficiou não só a esquerda, mas principalmente os civis partícipes do golpe e da ditadura, e contribuiu, ainda, para gerar um esquecimento de que houve militares que não tomaram parte no regime e que foram punidos por se oporem a ele. Acredito, portanto, que houve o que Pollak (1989: 9-12 e 1992: 206) chama de um trabalho de enquadramento da memória nacional, no sentido de estabelecer uma referência que excluiu os civis de todas as responsabilidades pelos excessos do regime instaurado em 1964. Como esse trabalho é executado parcialmente pelos historiadores, uma questão que surge é saber até que ponto os analistas brasileiros contribuíram para a constituição dessa memória nacional sobre a ditadura. Focaram suas análises na questão da dicotomia entre democracia e autoritarismo e ignoraram o conflito político-ideológico que precedeu e envolveu a tomada do poder em 1964? Ou preferiram a constituição de uma memória que priorizasse a conciliação nacional em detrimento de outra que expressasse e, talvez, acentuasse as divergências e os conflitos entre diferentes grupos da sociedade brasileira? Não é, no entanto, um objetivo do presente artigo responder a tais questões.

\section{Memória como elemento de disputa: as vozes dos militares vencidos em 1964}

Como foi dito, em certo momento, uma determinada memória se encontra em posição de domínio. Mas essa supremacia não significa necessariamente o apagamento de outras memórias. $\mathrm{O}$ fato de uma se tornar dominante não quer dizer que seja a única. Segundo Pollak (1989: 4-8 e 1992: 204-205), em momentos de crise, as memórias que são mantidas nos subterrâneos vêm à tona, e há uma disputa entre elas. Além disso, apesar do caráter destruidor, uniformizador e opressor da memória coletiva, as memórias subterrâneas são transmitidas de geração a geração, e o longo silêncio, ao invés de produzir o esquecimento, gera uma resistência aos discursos oficiais.

Em geral, essas memórias "proibidas" sobrevivem guardadas em estruturas de comunicação informais (famílias, associações, redes de sociabilidade afetiva ou política) e passam despercebidas pela sociedade. Os problemas que elas encontram são, no longo prazo, o de sua transmissão intacta, e, cotidianamente, o da complexidade de se encontrar uma escuta. Se os militares que detiveram o poder durante 21 anos já mencionam a dificuldade de combater a memória pública, para os que lutaram contra eles é difícil conseguir quem simplesmente os ouça. 
A existência de uma memória subterrânea guardada e resistente em um determinado grupo, seu esforço em se fazer ouvir e a dificuldade para consegui-lo podem ser percebidos no exemplo das associações que reúnem militares cassados pela ditadura.

Do golpe até meados da década de 1970, a forte repressão intimidou esses homens a lutar pelos seus direitos. Somente com o início da liberalização do regime, a partir do governo do general Ernesto Geisel, os militares cassados puderam se dedicar a essa tarefa. No que se refere ao período que vai de meados dos anos 1970 até 1979, quando da promulgação da Lei da Anistia, ${ }^{9}$ as informações a respeito da atuação desses homens é escassa, embora ela tenha ocorrido, só que dentro de um contexto mais geral da pressão da sociedade civil por esse benefício. Só após a promulgação dessa lei, e a consequente insatisfação com o que lhes foi concedido, e em um clima de menor repressão, é que esse silêncio foi realmente quebrado, e os militares cassados passaram a protestar e a reivindicar os seus direitos.

Exemplo desse fato foi a produção pelos militares cassados de um documento que denunciava que o projeto formulado pelo governo visava a "anistiar ampla, geral e irrestritamente só aos torturadores e terroristas oficiais", sem apresentar nenhum compromisso em recolocá-los nos "lugares onde deveriam estar" 10 caso não tivessem sido atingidos pelos Atos Institucionais.

A elaboração e a divulgação desse documento não foi um caso isolado.

Os cassados produziram um conjunto de documentos que foram levados aos parlamentares com o objetivo de mostrar que a lei, caso fosse aprovada nos termos do projeto do governo, não os atenderia em seus anseios. Baseavam-se, principalmente, nas anistias anteriormente concedidas no Brasil, que foram amplas e reintegraram os militares nas carreiras, não contendo as restrições presentes no projeto de $\mathrm{Fi}$ gueiredo. (Machado, 2006: 88)

Portanto, apesar do longo silêncio, em um momento de crise para o regime a memória reprimida dos militares cassados encontrou um espaço para tentar se fazer ouvir. Mas, mesmo hoje, eles ainda não se encontram satisfeitos com o espaço conseguido junto à memória pública, como se percebe através do projeto anunciado pelo professor Ivan Cavalcanti Proença (2004: 163-165), capitão do Exército em 1964, cassado e membro da Associação Democrática e Nacionalista dos Militares (Adnam), de publicar as memórias dos militares punidos pelo regime em resposta à série de livros lançada pela Biblioteca do Exército. 
A edição das memórias e autobiografias dos militares que participaram do regime e o anúncio do projeto dos militares cassados é uma prova de que há um processo de disputa. A memória "oficial" definiu a ditadura como exclusivamente militar e imputou toda a carga negativa desse período a eles, gerando uma reação dos golpistas, que tentam marcar o que, supostamente, seu período no governo teve de positivo. Por sua vez, a réplica destes resultou numa resposta dos cassados. E para análise dos relatos dos militares punidos pela ditadura, creio que as questões do trauma e da constituição do grupo apresentam boas perspectivas.

\section{O trauma como possibilidade de análise}

Nem todo esquecimento decorre de uma manipulação política. Como já foi mencionado, há também um esquecimento passivo, decorrente da própria impossibilidade de se lembrar de tudo, e outro deliberado, necessário, fruto, por vezes, do sentimento de impossibilidade do indivíduo de lidar com determinada memória traumática. Para superar esses traumas de difícil convivência que o passado pode gerar, muitas vezes silencia-se.

Esse é o caso do brigadeiro Ricardo Nicoll, cassado em 1964, quando era comandante do Comando dos Transportes Aéreos (Comta). Em material cedido ao pesquisador Hélio Silva, ao contrário de outros militares que prestaram depoimentos no mesmo projeto e se detiveram sobre as amarguras do golpe e das cassações, o brigadeiro Nicoll preferiu se ater aos momentos da criação do Correio Aéreo Militar e à abertura da rota que hoje constitui o Correio Aéreo Nacional, quando a Aviação ainda era a $5^{\text {a }}$ Arma do Exército (Silva, 1988: 195-201). Portanto, optou por relatar "tempos felizes" nos quais as Forças Armadas tiveram um papel de integração entre as regiões e os povos do Brasil. Como conclui Hélio Silva a respeito do relato do brigadeiro, "Há tempo para tudo. $\mathrm{O}$ aviador pioneiro, com a fé-de-serviço que honra a Aviação Brasileira, preferiu recordar os bons tempos a viver, ou melhor, reviver o drama escrito por seus companheiros."'(Silva, 1988: 2.201).

A opção do brigadeiro Nicoll, e de outros como ele, de deixar de relatar sua experiência de dor, preferindo lembrar um tempo mais feliz, deve ser respeitada. Mas essa vontade de não querer mais falar sobre algo, em certos momentos, se aproxima da omissão e nem sempre é suficiente para afastar acontecimentos que produziram e produzem traumas. Por essas razões, enquanto uns esquecem, outros preferem falar. Se essa lembrança não leva à superação do trauma, algumas vezes, ao menos, proporciona o alívio. 
Esse me parece ser o caso de Waldemar Dantas Borges, cassado em 1964, quando era tenente-coronel do Exército. Em depoimento concedido a Hélio Silva (1988: 156-160), com o intuito de apresentar uma lembrança que considerava rica, o militar optou por relatar notas de um diário que escreveu durante os quase dois meses em que esteve preso. $\mathrm{O}$ depoimento é marcado pela amargura e pelo ressentimento com o tratamento que ele e os demais militares presos receberam dos companheiros de tropa. Em sua conclusão, escrita em março de 1988, percebe-se que essa mágoa o marcou profundamente e que o trauma permanecia vivo muitos anos depois. Em tom de desabafo ele escreveu:

Este depoimento é uma denúncia contra os violentadores de nossos valores castrenses, nunca um lamento. Orgulho-me de estar do lado oposto dos golpistas. Creio na instituição militar que amei e amo. Meu Exército adoeceu em 1964 de doença cruel, martirizante, mas vai recuperar-se. As minhas Forças Armadas não são de 1964, que exorbitaram e ainda hoje tentam reagrupar-se em associações espúrias e insensatamente querem a volta da ditadura militar. Homens insensíveis, psicopatas que violaram o templo sagrado dos quartéis, transformando-os em câmaras de tortura, onde, comprovadamente, mataram, inutilizaram e mutilaram tantos irmãos e irmãs brasileiros. Os golpistas de 64, além de todos os males causados ao país, além de assassinarem os valores sagrados da convivência castrense, além das perseguições, injustiças, enfim, toda a sorte de arbitrariedade, praticaram - direta ou indiretamente - o mais nefando dos crimes: a tortura, imperdoável degradação da pessoa humana. Covardia! E o quartel não é lugar de covardes, razão por que serão banidos e a mancha que produziram vai demorar, desgraçadamente, mas será removida e o povo brasileiro voltará a orgulhar-se de seus soldados. (Silva, 1988: 160)

Porém, se a exploração do trauma gera possibilidades de análise e muitas vezes proporciona alívio ao depoente, ela também pode ter um lado negativo, que é o de transformar as vítimas em mártires, apagando a história política do conflito, a disputa entre as diferentes visões de futuro que se chocavam. A meu ver, no processo de construção da memória coletiva sobre a ditadura, o trauma decorrente dos 21 anos de ditadura teria provocado, já a partir dos últimos momentos do regime, algo desse tipo: a vitimização absoluta dos civis e a negativização da categoria militar. Gerou-se, então, a dicotomia: de um lado os civis, o certo, o democrático, o bom; de outro, os militares, o errado, o autoritário, o mal. Essa visão contribuiu para sufocar a existência de um conflito político-ideológico anterior a 1964, no qual havia civis e militares em ambos os lados. Serviu, tam- 
bém, para que se evitasse o questionamento das responsabilidades de civis, inclusive quanto a arbitrariedades políticas e torturas, durante a ditadura.

Pode ser que Paul Ricoeur (2002: 75) esteja certo quando afirma que uma parte da sociedade não pode viver em estado de permanente cólera contra outra parte dela mesma. Nesse sentido, a construção desse esquecimento teria um aspecto positivo, ao procurar conciliar adversários. Contudo, creio que esse processo serviu mais a um grupo político civil que, isento da nódoa do autoritarismo, pode permanecer desfrutando da intimidade do poder.

Esquecer, portanto, pode até aliviar o trauma individual, mas lembrar é um dever social. As arbitrariedades, o autoritarismo, as responsabilidades dos senhores (militares e civis) que tomaram o poder em 1964, e os conflitos político-ideológicos inerentes a essa questão, não podem ser esquecidos. Na busca desse objetivo, concordo com a afirmação de Dora Schwarzstein (2001: 79) de que a história oral de traumas pode permitir a apresentação de elementos do passado com capacidade de contribuir para a elaboração de uma consciência histórica que atravesse gerações e culturas diferentes. Desse modo, proponho uma atenção às vozes dos militares atingidos pela repressão da ditadura no Brasil. Há que se cuidar para não transformá-los em mártires, mas é preciso permitir que eles validem suas memórias contra aquela que se tornou dominante e contra os que negam a disputa ideológica.

\section{O grupo como objeto de análise}

A memória é uma construção social. É na interação com a sociedade, grupos e instituições que construímos as nossas lembranças. Portanto, o pertencimento a um determinado grupo influi na construção da memória individual. Nesse sentido, torna-se útil ao historiador o conceito de "geração". A análise de um conjunto de indivíduos que compartilha experiências sociais historicamente distintas das de outros pode contribuir para a compreensão da história, não só do grupo, mas também de um dado momento de uma sociedade. Mas é preciso atentar para o fato de que, como afirma Jean-François Sirinelli (1996: 133), "um extrato demográfico só se torna uma geração quando adquire uma existência autônoma e uma identidade - ambas geralmente determinadas por um acontecimento inaugurador".

Para o caso dos militares punidos pela ditadura, a cassação e a anistia funcionaram como marcos construtores de identidade - não só no que ser refere a eles próprios, mas também com relação à sociedade. Esses fatos geraram um sentimento de pertencimento ao grupo, possibilitando a cada membro um sentido de unidade, de continuidade e de coerência. 
Existem, no entanto, identidades coletivas construídas anteriormente por esses mesmos homens. Há, por exemplo, os grupos formados em torno das chapas nacionalistas durante as disputas nas eleições do Clube Militar ao longo dos anos 1950, da defesa da legalidade nessa mesma década e no início dos anos 1960, dos marinheiros e sargentos que lutavam por melhorias para suas classes através de movimentos reivindicatórios no início dos anos 1960. A identidade de cassados unificou esses diferentes grupos em torno de um objetivo comum. Porém é importante destacar outro elemento fundamental para a constituição da identidade desses grupos: a existência de um projeto.

Segundo Gilberto Velho,

se a memória permite uma visão retrospectiva mais ou menos organizada de uma trajetória e biografia, o projeto é a antecipação no futuro dessas trajetória e biografia, na medida em que busca, através do estabelecimento de objetivos e fins, a organização dos meios através dos quais esses poderão ser atingidos. (Velho, 1994: 101)

A princípio, independente de constituírem um grupo formalmente definido ou não, esses militares possuem uma identidade adquirida em função de um acontecimento inaugurador: foram cassados pelo regime civil-militar instaurado em 1964. Mas essa identidade é reforçada no momento em que ocorre a formalização de um grupo em torno de um objetivo, de um projeto comum: a luta pela anistia. As associações de militares cassados foram criadas com esse objetivo.

Embora não tratando especificamente dessa questão, e tampouco visando a reconstituir as memórias de militares, o trabalho de Flávia Burlamaqui Machado (2006) nos fornece elementos interessantes para essa discussão. Com base em documentação e no relato de alguns militares cassados que foram ativos na luta pela anistia, Machado descreve o momento em que eles optam por uma atuação organizada: o da insatisfação com a Lei da Anistia concedida pelo regime. ${ }^{11}$ Portanto, se 1964 foi o acontecimento fundador que criou entre esses militares a identidade de cassados, foi o projeto de luta pela ampliação da Lei da Anistia que transformou essa geração de militares em um grupo de fato. A partir da definição desse projeto, esses militares passaram a definir sua trajetória.

Desde 1979, em discussões que envolviam pequenos grupos espalhados pelo Brasil, eles já apresentavam uma insatisfação com relação à lei, entre outros motivos, por tê-los mantido nos postos que tinham na época de cassados (Machado, 2006: 93). Em função desse descontentamento e com o objetivo de intensificar a luta, resolveram fundar uma associação. Nas palavras de Luiz Carlos Moreira, cassado pelo regime quando era segundo-tenente da Marinha: 
Nós começamos a produzir documentos para mostrar aos deputados que aquilo não trouxe nenhuma, não reparou coisa alguma, não promoveu nenhum ressarcimento, não restabeleceu os nossos postos e nós continuávamos prejudicados, nós nos sentimos novamente cassados, mais uma vez cassados. Porque a leitura do texto fez com que concluíssemos que o propósito do governo era anistiar os torturadores. Essa coisa foi causando uma certa indignação em todos nós, e nós fomos ao Congresso e vimos que o Congresso estava "agachado". [...] Em 1979 eram parlamentares receosos e não estavam dispostos a desagradar os comandos militares. Tivemos pouco êxito lá em 1979. Aí concluímos que tínhamos que fundar uma entidade. (Machado, 2006: 89)

Assim, em 1980, formaram a Associação dos Militares Cassados (Amic), com o objetivo de empreender uma luta mais organizada em defesa dos direitos violados em 1964. Em 1983, com a adesão de militares ligados ao Partido Comunista Brasileiro (PCB), mudaram o nome da entidade, passando a chamá-la de Associação Democrática e Nacionalista dos Militares (Adnam) (Machado, 2006: 99). A partir dessa mudança, ampliou-se o leque de preocupações da Associação para além da questão da anistia, e as atividades passaram a se pautar mais por discussões políticas do que por ações efetivas. A partir de 1985, no entanto, com a convocação da Assembleia Nacional Constituinte, voltaram a intensificar as suas ações. Foi criado o "Comitê Nacional de Coordenação da Anistia Ampla, Geral e Irrestrita”, que passou a pressionar o Congresso pela ampliação da lei. Aos poucos esse movimento ganhou corpo, e outras entidades, como a Associação dos Militares Incompletamente e Não-Anistiados (Amina), que reunia militares cassados por terem participado do Levante Comunista de 1935 e da campanha "O Petróleo é Nosso" na segunda metade dos anos 1940, e o grupo Tortura Nunca Mais, se juntaram ao "Comitê", que foi então transformado em Federação das Associações de Defesa da Anistia (Fada).

A cada etapa do trâmite Constituinte (apresentação de proposta de emenda à Emenda Constitucional, curso pelas comissões do Congresso e votação do substitutivo, já durante a Constituinte), conseguiram ampliar seus direitos, mas sempre muito aquém do desejado. Após a promulgação da Constituição, embora os objetivos não tivessem sido atingidos na sua plenitude, a atuação da Adnam sofreu uma baixa no que se refere à luta pela anistia. Muitos de seus membros se afastaram, e ela retomou o formato de tribuna de discussões nacionalistas. Somente no governo do presidente Fernando Henrique Cardoso, com a criação da Comissão de Anistia, a Adnam retomou sua atuação no que se refere à luta pela anistia. ${ }^{12}$ 
É inegável que só o fato da cassação já é um elemento importante na constituição da memória desses homens. Mas, por certo, a insatisfação com a anistia concedida em 1979 - e a consequente formação de uma associação que conseguiu reconhecimento e cresceu, bem como, depois, o surgimento de federações de entidades em luta pela anistia - foi fundamental para a coesão desses militares. Isso fica mais claro quando, a partir da promulgação da Constituição de 1988, com o atendimento de parte das reivindicações, portanto, do "projeto" dos cassados, a Adnam passa a viver um momento de refluxo.

A participação nesse processo e a filiação a essas associações produziram um sentimento de identidade entre esses homens e, por fim, também contribuíram para a constituição da memória dos membros dessa geração. Desse modo, em uma via de mão dupla, o analista que se debruçar sobre o estudo de memórias dos militares cassados (e de qualquer outro grupo) deve sempre atentar para o fato de que o pertencimento a uma determinada comunidade influiu na construção da memória individual. Outrossim, o processo de constituição de biografias coletivas, o entrecruzamento das múltiplas histórias de vida desses homens, pode possibilitar a compreensão da história não só desse grupo particular, mas, também, da ditadura implantada no Brasil em 1964.

\section{Conclusão}

O testemunho, por si só, não é história. Não basta recuperá-lo e transmiti-lo. Um analista que opte por trabalhar com depoimentos precisa levar em consideração o processo complexo de construção da memória, permanecendo atento a seu caráter coletivo, seletivo, e à interação permanente entre passado e presente durante todo esse processo. É preciso relacionar os depoimentos à conjuntura na qual eles foram produzidos e àquela a que eles estão se referindo. É imprescindível, ainda, analisar a constituição, as características, os conflitos e as escolhas do grupo a que o depoente pertence; os mecanismos através dos quais esses depoimentos são construídos; a forma como eles passaram de geração para geração; e a disputa política em torno da constituição da memória pública. Torna-se necessário, também, entrecruzar esses depoimentos entre si e com outras fontes. Só assim poderemos formar um retrato o mais fiel possível do passado.

Tomando os cuidados necessários, que, aliás, devem ser observados na análise de toda e qualquer fonte histórica, as memórias podem servir como valioso elemento para o estudo de um grupo e de uma época. Ainda mais para casos como os dos militares cassados pela ditadura instaurada em 1964, cujas memórias foram silenciadas, sufocadas, reprimidas pela memória pública construída em torno do tema e para as quais as fontes oficiais ou são raras, ou não estão disponíveis à pesquisa. 
Ao trazer à luz esses testemunhos, será possível tornar conhecidas as experiências de indivíduos cuja participação e visão dos momentos históricos e das questões que envolvem a tomada do poder em 1964 correm o risco de se perder. O historiador não pode permitir que esse desconhecimento prossiga e atinja as gerações futuras. Resgatar essas vozes, contribuindo para que elas ganhem espaço no discurso público, é sua função. Agindo assim, além de transformar a memória em história, ele estará contribuindo para democratizá-la.

Notas

1. As conclusões apresentadas não fazem referência explícita às introduções da trilogia de livros de depoimentos organizada por Maria Celina D’Araujo, Gláucio Ary Dillon Soares e Celso Castro (1994; 1994; 1995), pelo fato de que nelas não há análises mais detidas sobre a memória militar e/ou conclusões sobre o golpe e a ditadura construídas com base nos relatos. A intenção dos autores, nessas introduções, foi mais apresentar (fazendo uma breve análise) os contextos aos quais os depoimentos se referiam. Creio que os trabalhos individuais de D'Araujo (1994) e Soares (1994) são mais específicos no que se refere a analisar e apresentar conclusões a partir dos depoimentos dos militares concedidos ao CPDOC/FGV.

2. Há outros importantes elementos na constituição da memória, como a flutuação, a reordenação e a memória herdada. Contudo, para a presente análise, creio que os três aspectos destacados são os mais significativos.

3. Questiono, também, a opção de Soares de adotar a página como unidade de análise. Soares se propõe fazer um estudo quantitativo, e estabelece que um fator explicativo seria considerado mais relevante na medida em que fosse citado em um maior número de páginas. Mesmo que aparecesse várias vezes em uma mesma unidade, para efeito de análise, seria considerado como apenas uma citação. Uma primeira consideração a ser feita é que os relatos têm extensões diferentes. Desse modo, o depoimento mais extenso de um militar qualquer pode acabar sendo mais relevante para a conclusão final do que o de outro que tenha sido mais conciso, visto que, teoricamente, permite um maior número de citações. Além disso, uma simples modificação da editoração das obras e das entrevistas pode levar a um resultado diverso e a conclusões conflitantes com as apresentadas por Soares.

\section{A coleção História oral do Exército - 1964: 31 de março. O movimento revolucionário e sua história, editada pela Bibliex, é composta de 15 volumes com relatos de militares que participaram do regime e de alguns civis \\ colaboracionistas.}
5. Maria Celina D'Araujo estuda os mesmos depoimentos de militares prestados ao CPDOC analisados por Gláucio Soares. Mas, ao contrário de Soares, não examina as obras memorialísticas publicadas. 
6. Diferentemente dos trabalhos de D'Araujo e Atassio, Martins Filho não se debruça sobre um corpo particular de depoimentos. Seu objeto são todas as obras memorialísticas produzidas que contenham relatos de militares e militantes civis sobre a ditadura.

7. Martins Filho dá destaque a versões antagônicas, como a do general Fiúza de Castro, que discorda da tese de que os superiores não sabiam da tortura.

8. Na Argentina, segundo Huyssen, o consenso se fez em torno da idéia do desaparecido político como vítima, "esquecendo" a dimensão política da insurgência esquerdista que a ditadura queria eliminar. Já na Alemanha, de modo que a população alemã aceitasse a responsabilidade pelos crimes do governo de Hitler, "esquecendo" a memória dos bombardeios aliados sobre Dresden.

\section{Referências bibliográficas}

ARAUJO, Maria Paula. 2006. Estratégias de resistência e memória da luta contra o regime militar no Brasil (1964-1985). In: MARTINS Filho, João Roberto. O golpe de 1964 e o regime militar: novas perspectivas. São Carlos: EdUFSC.

ATASSIO, Aline Prado. 2007. A batalha pela memória: os militares e o golpe de 1964. Dissertação (Mestrado em Ciências Sociais) - Programa de Pós-Graduação em Ciências Sociais, Universidade Federal de São Carlos, São Carlos.

D’ARAUJO, Maria Celina. 1994. Ouvindo os militares: imagens de um poder que
9. Lei 6.683/79, aprovada sob o governo de João Batista Figueiredo em agosto de 1979.

10. "Dos militares cassados à nação brasileira". Acervo particular Fernando Santa Rosa, reformado em setembro de 1964 por força do Ato Institucional $\mathrm{n}^{\circ} 1$, de 9 de abril de 1964, quando tinha a patente de capitão-tenente da Marinha (Machado, 2006:87-88).

11. Já em 1964, militares cassados se reuniam visando à luta pela reincorporação às Forças Armadas. Contudo, somente com a Lei da Anistia, em um ambiente de abertura política, é que esse processo foi intensificado. Cf. Fundo de Polícias Políticas, pasta Secreto 11, p. 49, 83-85 e 142-144, sob guarda do Arquivo Público do Estado do Rio de Janeiro.

12. A Adnam mantém encontros regulares na sede da Associação Brasileira de Imprensa (ABI), no Rio de Janeiro.

se foi. In: FERREIRA, Marieta de Moraes (coord.). Entre-vistas: abordagens e usos da história oral. Rio de Janeiro: FGV.

; SOARES, Gláucio Ary Dillon; CASTRO, Celso. 1994. Visões do golpe: a memória militar sobre 1964. Rio de Janeiro: Relume-Dumará.

1994. Os anos de chumbo: a memória militar sobre a repressão. Rio de Janeiro: Relume-Dumará.

1995. A volta aos quartéis: a memória militar sobre a abertura. Rio de Janeiro: Relume-Dumará. 
HALBWACHS, Maurice. 1990. $A$ memória coletiva. São Paulo: Vértice.

HUYSSEN, Andreas. 2004. Resistência à memória: os usos e abusos do esquecimento público. In: Intercom. Porto Alegre. Mimeografado.

MACHADO, Flávia Burlamaqui. 2006. As Forças Armadas e o processo de anistia no Brasil (1979-2002). Dissertação (Mestrado em História) PPGHIS-UFRJ, Rio de Janeiro.

MARTINS Filho, João Roberto. 2002. A guerra da memória: a ditadura militar nos depoimentos de militantes e militares. Varia Historia, Belo Horizonte, n. 28.

POLLAK, Michael. 1989. Memória, esquecimento, silêncio. Estudos Históricos, Rio de Janeiro, vol. 2, n. 3. 1992. Memória e identidade social. Estudos Históricos, Rio de Janeiro, vol. 5, n. 10.

PROENÇA, Ivan Cavalcanti. 2004. $O$ golpe militar e civil de 64: 40 anos depois. Rio de Janeiro: Oficina do Livro.

RICOEUR, Paul et alii. 2002. La memoria contra el olvido. In:

BARRET-DUCROQ, Françoise (dir.)

¿Por qué recordar?. Buenos Aires: Granica.

ROUSSO, Henry et alii. 2002. La necessidad de olvido. In:
BARRET-DUCROQ, Françoise (dir.)

¿Por qué recordar?, Buenos Aires:

Granica.

SALVATICI, Silvia. 2005. Narrativas de violência no Kosovo do pós-guerra. História Oral. Revista da Associação Brasileira de História Oral, vol. 8, n. 1.

SCHWARZSTEIN, Dora. 2001. Historia oral, memória e histórias traumáticas. História Oral. Revista da Associação Brasileira de História Oral, n. 4.

SILVA, Hélio. 1988. A vez e a voz dos vencidos. Petrópolis: Vozes.

SIRINELLI, Jean-François. 1996. A geração. In: FERREIRA, Marieta de Moraes \& AMADO, Janaína (orgs.). Usos e abusos da história oral. Rio de Janeiro: FGV.

SOARES, Gláucio Ary Dillon. 1994. O Golpe de 64. In: SOARES, Gláucio Ary Dillon \& D'ARAUJO, Maria Celina. 21 anos de regime militar: balanços e perspectivas. Rio de Janeiro: FGV.

SODRÉ, Nelson Werneck. s. d. A interpretação de um nacionalista. In: Cadernos Cândido Mendes - História Oral. Rio de Janeiro.

VELHO, Gilberto. 1994. Projeto e metamorfose: antropologia das sociedades complexas. Rio de Janeiro: Jorge Zahar.

\section{Resumo}

Estudos baseados em fontes orais têm possibilitado boas reflexões sobre a ditadura implantada no Brasil em 1964. Entre elas, tem recebido especial atenção a memória dos militares partícipes do regime. De maneira inversa, a memória dos militares cassados tem recebido pouca atenção. Este artigo faz um balanço das principais análises da memória militar sobre a ditadura, tentando apresentar seus limites e levantar questões para o enriquecimento dos estudos sobre o tema.

Palavras-chave: ditadura militar, memória militar, militares cassados 


\begin{abstract}
Studies based on oral sources have produced good reflections about the dictatorship established in Brazil in 1964. Among them, the memory of Army officers that took part in the regime has received special attention. In contrast, the memory of the banished officers has been forgotten. This paper examines the main analysis of military memory of the dictatorship in order to show their limits and to point issues that could enrich the studies on this subject.
\end{abstract}

Key words: military dictatorship, military memory, banished officers

\title{
Résumé
}

Les études utilisant des sources orales ont produit des réflexions intéressantes sur la dictature instalée au Brésil en 1964. Parmi ces sources, la mémoire des militaires qui ont participé au régime a reçu une attention particulière. Par contre, la mémoire des militaires chassés a été oubliée. Cet article fait un bilan des principales analyses de la mémoire militaire sur la dictature, en essayant de présenter leurs limites et de poser des questions pour enrichir les études sur le thème.

Mots-clés: dictature militaire, mémoire militaire, militaires chassés 